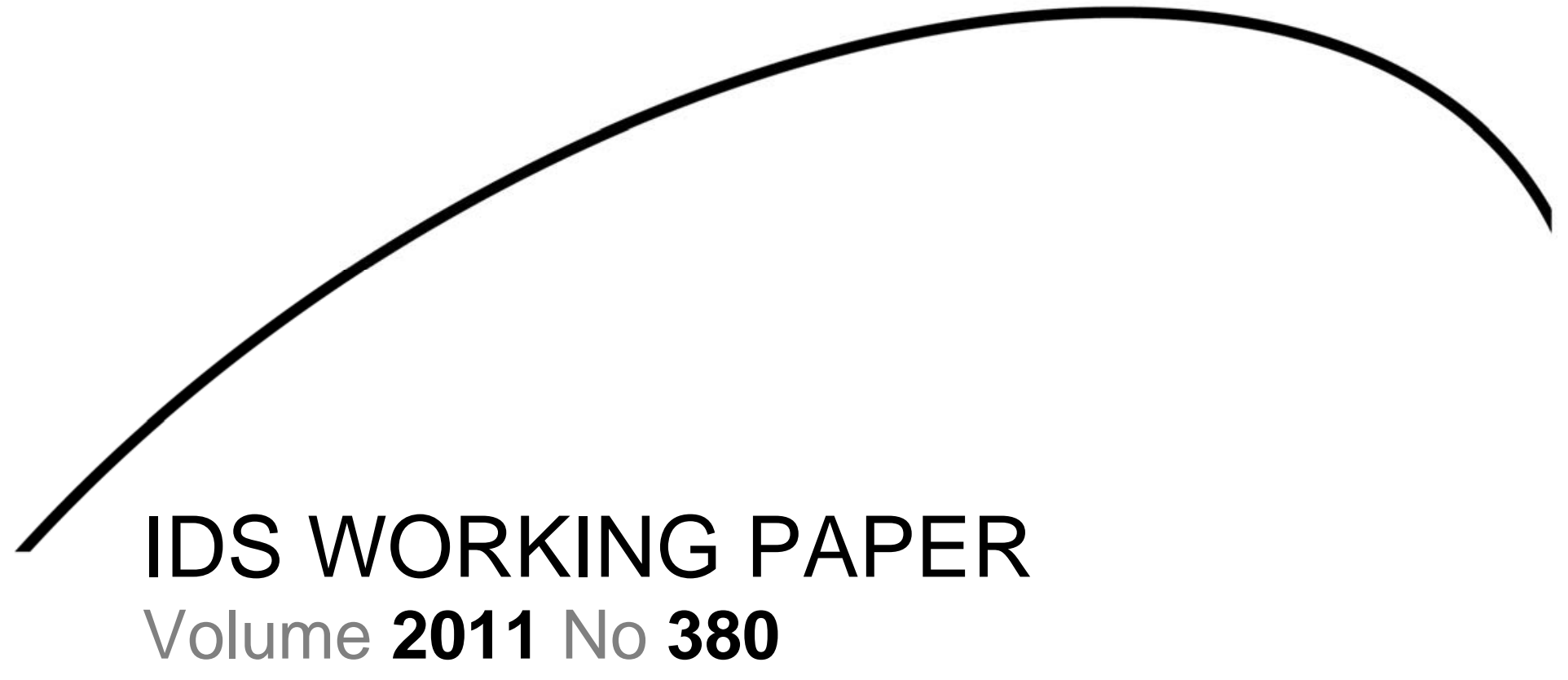

Poverty, Livelihoods and War Legacies: The Case of Post-War Rural Kosovo

Elodie Douarin, Julie Litchfield and Rachel Sabates-Wheeler November 2011

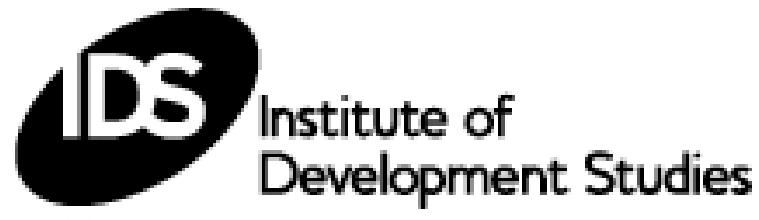


The Conflict, Violence and Development Research Cluster is part of the Vulnerability and Poverty Reduction Team at the Institute of Development Studies. The Cluster's main focus is to develop new insights into how people in contexts of conflict and violence live and interact, and what institutions help (or hinder) them. We aim to use our research findings to inform, identify and develop policies and practices that will strengthen people's own efforts to survive and make a living.

Email: conflict@ids.ac.uk

Web: www.ids.ac.uk/go/research-teams/vulnerability-and-poverty-reduction-team/researchthemes/conflict

\section{CVD WP2}

Poverty, Livelihoods and War Legacies: The Case of Post-War Rural Kosovo

Elodie Douarin, Julie Litchfield and Rachel Sabates-Wheeler

IDS Working Paper 380

First published by the Institute of Development Studies in November 2011

(C) Institute of Development Studies 2011

ISSN: 1353-6141 ISBN: 978-1-78118-031-0

A catalogue record for this publication is available from the British Library.

All rights reserved. Reproduction, copy, transmission, or translation of any part of this publication

may be made only under the following conditions:

- with the prior permission of the publisher; or

- with a licence from the Copyright Licensing Agency Ltd., 90 Tottenham Court Road, London

W1P 9HE, UK,

or from another national licensing agency; or

- under the terms set out below.

This publication is copyright, but may be reproduced by any method without fee for teaching or nonprofit purposes, but not for resale. Formal permission is required for all such uses, but normally will be granted immediately. For copying in any other circumstances, or for reuse in other publications, or for translation or adaptation, prior written permission must be obtained from the publisher and a fee may be payable.

Available from:

Communications Unit, Institute of Development Studies, Brighton BN1 9RE, UK

Tel: +44 (0) 1273915637 Fax: +44 (0) 1273621202

E-mail: bookshop@ids.ac.uk

Web: www.ids.ac.uk/ids/bookshop

IDS is a charitable company limited by guarantee and registered in England (No. 877338) 


\title{
Poverty, Livelihoods and War Legacies: The Case of Post-War Rural Kosovo
}

\author{
Elodie Douarin, Julie Litchfield and Rachel Sabates-Wheeler
}

\begin{abstract}
Summary
This paper examines the effects of war on livelihood portfolios and welfare outcomes of rural households in Kosovo using the 2000 Kosovo Living Standards Measurement Survey. We question to what extent the legacy of war was experienced through selection into low return livelihood activities or through decreases in welfare generally. We first identify portfolios using a clustering algorithm which groups households pursuing similar combinations of activities. The emerging clusters are comparable to those described in more qualitative studies for Kosovo in the immediate post-conflict period. We then examine the determinants of livelihood portfolio choice and the consequences of these for welfare outcomes, controlling for war legacies and selection into specific portfolios. We find evidence of a relationship between a household's war experience and their livelihood choices and that war exposure has different impacts on household welfare depending on the livelihood portfolio adopted. We also identify significant selection effects on welfare for three out of four of our livelihood clusters, highlighting the fact that selecting into a specific portfolio raised or lowered welfare above expected levels.
\end{abstract}

Keywords: clusters; Kosovo; livelihood; post-conflict; selection model; welfare.

Elodie Douarin is a Research Fellow in the Department of Economics at the University of Sussex. Her main research interests lie in the field of agricultural economics and rural development, with specific focuses on land distribution and land market imperfections, as well as credit access and investment in transition and developing countries and agricultural/rural labour markets and adjustment to policies in developed, developing or transition economies. Her most recent research work has concentrated on the economics of conflicts, as part of the MICROCON project. In particular, she is looking at post-war rural livelihood in Kosovo and the links between land distribution, perceived fairness and land disputes in Kyrgyzstan.

Julie Litchfield is a Senior Lecturer in the Department of Economics at the University of Sussex, specialising in development economics. The main themes of her research are poverty, inequality and income distribution. She recently completed a three-year DfID-funded research project on trade reform and poverty dynamics in Zambia, China and Vietnam, an analysis of Inequality in Latin America, and she is member of the Sussex Development Research Centre on Migration, Poverty and Development. Her current research includes analysis of the relationship between conflict and poverty with the MICROCON project and work on migration and poverty in Albania. She is currently on secondment to DFID as Senior Research Fellow working on agriculture and growth.

Rachel Sabates-Wheeler is a Development Economist with extensive experience in rural development, institutional analysis and social protection. A Research Fellow at the Institute of Development Studies since 2001, she has been a Director of the Centre for Social Protection since 2006. Prior to coming to IDS Rachel's geographic research focus was primarily in Eastern Europe and Central Asia. Since joining IDS she has worked with poverty analysis work relating to PRSPs, social protection and migration in over 7 African countries. She has recently co-edited a book entitled Migration and Social Protection: Claiming Social Rights Beyond Borders. 


\section{Contents}

Summary, keywords, author notes 3

Acknowledgements $\quad 5$

Introduction $\quad 6$

$1 \quad$ The conflict in Kosovo $\quad 7$

2 Data 9

2.1 War legacies 9

$\begin{array}{ll}2.2 \text { Welfare } & 10\end{array}$

$3 \quad$ Livelihoods and portfolio identification $\quad 11$

$4 \quad$ The effect of war on livelihood choice and welfare outcomes 16

4.1 Selection into livelihood clusters: the multinomial logit results 17

$\begin{array}{ll}4.2 & \text { Selection effects on welfare } \\ & 19\end{array}$

$5 \quad$ Discussion and conclusions $\quad 22$

$\begin{array}{lll}\text { Annex } 1 & \text { Discarded observations } & 24\end{array}$

Annex 2 Cluster analysis methods and robustness check 26

$\begin{array}{ll}\text { References } & 28\end{array}$

Tables

Table 2.1 Housing Damage Index 10

Table 3.1 Distribution of income sources in the rural sample 13

Table 3.2 Cluster descriptions 13

Table 3.3 Cluster profiling 14

Table 4.1 Consumption estimates for full sample, OLS 17

Table 4.2 Summary results (sign and significance) of multinomial logit for war variables, land and ethnicity, by livelihood cluster 18

Table 4.3 Welfare estimation results with correction for selectivity bias, by livelihood Cluster

Table A1 Characteristics of the observations kept, logistic regression 25

Table A2 Cluster and household labour allocation 27 


\section{Acknowledgements}

This research was funded by the European FP6 project MICROCON and this paper first appeared as MICROCON Research Working Paper 37 in November 2010. MICROCON was a five-year European Commission FP6 research programme, running from 2007 to 2011. It took an innovative micro level, multidisciplinary approach to studying the conflict cycle, promoted understanding of individual and group interactions leading to and resulting from violent mass conflicts, and aimed to better inform conflict policy and place individuals and groups at the centre of interventions. For more information please visit the website www.microconflict.eu/

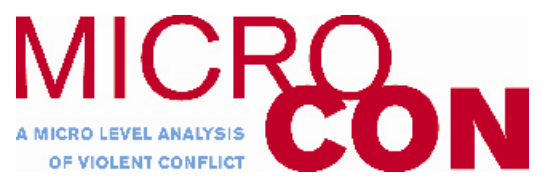

Data was collected by the Statistical Office of Kosovo and distributed by the World Bank LSMS office. The authors would like to thank participants of two seminars given at the University of Sussex and IDS for useful comments on a previous version of the paper. The usual disclaimer applies.

A revised version of this paper has been accepted for publication in the Journal of Agricultural Economics. 


\section{Introduction}

There are many possible effects of conflict on household welfare. Most obviously, violent conflict leads to death, injury and household dislocation and fragmentation. Less dramatic, but with potentially long-term devastating effects, conflict undermines livelihoods causing some people to switch into coping strategies, such as migration, reliance on assistance, or moving into low-risk but possibly low-return farming or employment strategies. This paper examines the extent to which conflict affected livelihood choice in the immediate postconflict period in rural Kosovo and whether the effects of conflict had wider welfare impacts.

There is a vast literature on how households adopt ex ante and ex post strategies in response to shocks. Morduch (1995), Dercon (1998, 2005), Dercon and Krishnan (1996) show that households anticipate economic shocks by adopting low-risk but low return activities, i.e. activities that allow for smooth but low consumption levels in the presence of risk. To reduce exposure to risk, households may seek to diversify activities and select activities with lower levels of contingent risks (Block and Webb 2001; Deininger and Okidi 2003), including sending members of the household away so as to provide remittances (Calero, Bedi and Sparrow 2009). They may also seek to accumulate assets (land or livestock for example), particularly in the absence of credit markets, or in anticipation of loss of access to those markets, as these assets can be liquidated to smooth consumption following an exposure to economic shocks (Binswanger 1981; Fafchamps, Udry and Czukas 1998; Rosenzweig and Wolpin 1993; Dercon and Krishnan 1996). A further possibility is that households may turn to support networks, either formal or informal (Dercon 2005).

In the context of conflict, these choices may be severely constrained, and may not represent choices at all. Furthermore the choice and efficacy of these strategies may be limited by the covariant nature of the shock: coping with the death of a family member, and subsequent loss of income, may be much more difficult when one's neighbours and friends are experiencing the same shock. Similarly, distress sales of assets provide limited income when markets are flooded by other households doing the same. Hence the effect of conflict may go beyond influencing the choice of livelihoods facing households, by further reducing the effectiveness of those choices in enabling households to avoid poverty.

In this study, we seek to address explicitly the possibility that war legacies can affect both the choices available to households and the returns they can get from different livelihood choices. We do so by exploring, in the context of rural Kosovo, whether the legacy of war is confined to determining livelihood choices of households or whether the legacy of war persists further into affecting welfare outcomes of those choices. Our approach relies on the identification of the livelihood portfolios (that is, the combination of income generating activities) adopted by households in post-conflict rural Kosovo and then on modeling selection into this set of mutually exclusive livelihood portfolios and investigating whether, having controlled for this selection, welfare outcomes are further affected by war.

Our work aims to bring together two branches of the empirical literature on the effects of conflict on welfare - one that analyses the way conflict affects livelihood choice and a second branch that examines welfare outcomes after conflict. The first of these two branches is well exemplified by the work of Bozzoli and Bruck (2009) on Mozambique who show that households select different livelihoods depending on the availability of household resources, e.g. of labour and land, access to markets, and the incidence of social protection. The second branch is illustrated by the work of Justino and Verwimp (2008) and Ibanez and Velez (2008), where typically changes in poverty status, or welfare, are examined for households as a result of exposure to, or experience of, conflict. Put simply, our paper examines whether the legacy of war is confined to livelihood choice and hence has an 
indirect effect of household welfare, or whether it goes beyond that to have a further, direct, detrimental effect on household welfare.

We believe that this has important policy implications. If the legacy of war on household welfare is confined to its impacts on livelihood choices, then policy in post-conflict or in fragile states might be most effective if it focuses on ameliorating these impacts, through for example stabilising access to markets, re-establishing communication networks, providing short-term access to credit or other productive inputs, or implementing transformative social protection policies. If on the other hand, the legacy of conflict goes beyond these indirect effects, and has a further negative impact on household welfare, then it is likely that an appropriate policy response would also include cash and in-kind transfers, or other forms of social protection. We believe that Kosovo provides a useful case-study for our analysis as it is one of only a small number of countries for which detailed national household information is available for the immediate period after the end of conflict.

The structure of our paper is as follows. Section 1 provides some background to the conflict in Kosovo, with the aim of illustrating the severity of constraints surrounding livelihood choices. Section 2 describes the data and Section 3 details how we identify mutually exclusive livelihood portfolios, that is, indicators of household activities that go beyond the more traditionally used shares of income received from different activities (see for example Ellis, 2000). This section also presents our typology of household livelihood portfolios. Section 4 describes how we model livelihood selection, and its possible impact on welfare, and presents our results and Section 5 concludes.

\section{The conflict in Kosovo}

Within the Former Republic of Yugoslavia, Kosovo had long been a relatively autonomous entity but the rise of Serbian nationalism had resulted in a reversal of this situation (Ogden 2000; RIINVEST 2007). From 1991 until 1999, Belgrade promulgated increasingly discriminatory policies against the Albanian majority of Kosovo. By 1996 ethnic tensions were rising as the provision of public goods and services became increasingly erratic and discretionary, especially for the Albanian majority of Kosovo (Carter 1993). Migration of ethnic Albanians accelerated during this period, and an increasing number of ethnic Albanian families became reliant on migrant remittances (Ogden 2000). Tensions eventually culminated in the so-called 'Kosovo War' (1998-1999). The intense ethnic tensions and violent confrontations led to an 11-week NATO air campaign in spring 1999, that marked the official end of the war and led to the creation of the United Nation administered province of Kosovo in June 1999.

The conflict was marked by attacks on civilians and massive movements of people (see for example Alva et al. 2002 for a short summary) and resulted in dramatic losses in physical, human and social capital as well as insecurity over ownership of agricultural land and commercial property ownership (Smit 2006). UNHCR estimates (reported in World Bank 2001b: 15) indicate that about half a million ethnic Albanians were displaced within Kosovo during the conflict and an additional eight hundred thousand moved to neighbouring countries. Most of them came back in the months following the NATO air strike. It is also estimated that about two hundred thousand Serbs had left the province by the end of the war (World Bank 2001b: 128). The extent of destruction was immense, with notably about 70 per cent of the inhabited area being affected to some degree by the NATO air strike (European Commission 1999). The number of casualties in the civilian population was also large: it is estimated that by 1999, between ten and twelve thousand Albanians and over three thousand Serbs had lost their lives, mostly during confrontations between the Yugoslav 
military, Serbian police and Serbian paramilitary forces on one side and the Kosovo Liberation Army (KLA) on the other (Sklias and Roukanas 2007).

In the immediate after-math of the conflict, the population of Kosovo faced a complex situation where their livelihood choices were radically altered: infrastructure and housing was damaged or destroyed; crops had failed and agricultural land was ransacked, and in some cases mined. Furthermore, the contested political status of Kosovo meant that migration (to neighbouring Macedonia, Serbia, Montenegro and Albania) became more difficult, preventing individuals from taking advantage of the seasonal demand for unskilled workers in the region.

Westley and Mikhalev (2002) describe how the war created constraints across the economy, with households forced to fall back on limited coping strategies, including reliance on remittances from relatives working abroad, subsistence farming for household consumption, extended family/community safety nets, and humanitarian aid for the poorest. At the same time, those in receipt of remittances of sufficient size and reliable regularity were able to build up assets and diversify their livelihood activities, thus allowing them to recover more quickly after the conflict (via housing reconstruction, and restarting business and trade activities).

For agricultural households, Westley and Mikhalev describe how many households were unable to cultivate land on a commercial basis and were restricted to using just a portion of land for household subsistence. They note a variety of factors at work, including loss of equipment and draught animals, damage to irrigation systems as well as limited access to their land due to security reasons, including the presence of land mines and cluster bombs. In addition, lack of access to credit to invest in agriculture and to adequate and timely availability of agricultural inputs, combined with a loss of cross-border markets with Serbia and Montenegro, served to reduce incentives and opportunities for commercial agriculture. ${ }^{1}$ In a later study, Smit (2006) highlights that many displaced people were not able to regain access to commercial property or agricultural land and that legislation intended to expedite restitution has not been functioning adequately.

Ogden (2000) goes further and identifies the range of income sources that were available before and after the conflict. Remittances from the diaspora abroad remained an important source of income, but other income sources dried up after the war. For example sales of own production of corn, fruit, beans, grapes and vegetables was limited, and replaced by some households by trading in goods - food and household goods from overseas. Teachers, health and administrative staff were often not paid in the immediate post-war period, and formal jobs were limited to those with international organisations, with opportunities being greatest in the city and in larger towns. Previously available temporary and seasonal work in agriculture and construction was only minimally available in the months after the conflict. Gifts from family, friends, and neighbours were substantially diminished and credit was very much diminished. Pension payments went unpaid. Savings were held by a limited number of households, if they had not been lost or used during displacement. Income from sales of assets was limited, because of loss and damage.

1 Ogden (2000), based on semi-structured household interviews and discussions with key informants in July 1999 in mostly Albanian districts of Kosovo, reports that many households were reliant on food aid as a result of food insufficiency and the minimal harvest in 1999. She also reports that this was in part due to the presence of land mines and cluster bombs across rural areas, as well as by damage to machinery and loss or death of livestock as a result of the conflict. 


\section{Data}

The data used in this paper is drawn principally from the Living Standard Measurement Survey (LSMS), administered by the World Bank from September to December 2000 in Kosovo. This dataset constitutes a scarce example of a household survey conducted immediately after the end of a major conflict. Indeed, the data collection took place just over a year after the end of the NATO air bombing campaign that terminated the conflict in Kosovo.

The survey follows the standard LSMS questionnaire but was extended to include a more detailed agricultural module, a record of displacement episodes and information about social protection and the different forms of aid received by the local population. Community level data was also collected, and included specific records of recent changes in infrastructure and issues relating to displaced persons.

The survey was administered to a total of 2,880 randomly selected households. The sampling frame was complicated by the fact that no recent census could be used and that data collection was to be administered separately to the Serb and Albanian communities. In rural areas, the sampling frame was based on the European Commission's Housing Damage Assessment Survey, an extensive survey of damages to infrastructure and dwellings conducted in February 1999 and updated in June 1999, and a household-counting exercise carried out in non-covered areas. This allowed the identification of housing units, and one household was interviewed in each housing unit. In urban areas, a quick counting exercise was carried out so as to similarly identify housing units, which were then used as a basis for the sampling frame. The sampling method aimed at obtaining a representative sample of Serbs and Albanians in each municipality. However, the interviewed sample was slightly unbalanced ethnically and sampling weights based on the sampling design described above are used to correct for this.

Our analysis relies on specifying three key (sets of) indicators: conflict incidence or intensity, welfare and livelihoods. We discuss the conflict and welfare indicators here, but, in the absence of data on incomes received from different activities, we leave our discussion of the livelihoods indicators to the methodological section.

\subsection{War legacies}

A number of variables are used to measure conflict incidence and exposure (or war legacy). The LSMS contains several questions about the households' experience of war. These include whether or not the household is currently living in a temporary shelter or a damaged house, whether the household was displaced during the conflict (and remains displaced). In addition, households with land are asked about the presence of mines on their land, and about recent failures in crop harvests. Furthermore, community level data were collected on the share of houses having access to a range of infrastructure facilities in both 1997 and 2000, including electricity, piped drinking water, sewage, telecommunication and satellite TV. This allows us to construct variables that indicate whether households lost these services either during the later stages of the tensions and during the war itself.

Besides information extracted from the LSMS, one additional variable was created from an external source. To capture the intensity of the Kosovo war in different regions of the province, data from the Housing Damage Assessment Survey, completed in June 1999 (European Commission 1999) was used. This permits the construction of an index of damage intensity. Specifically, the level of destruction observed in towns and villages across Kosovo was used to compile an index capturing the level of housing damage at the municipality level. In each municipality, the index was constructed based on the extent of the 
damage (share of villages affected) as well as its intensity (the average share of destroyed dwelling per village), as presented in Table 2.1.

Table 2.1 Housing Damage Index

\begin{tabular}{|c|c|c|}
\hline Housing Damage Index & Share of damaged villages & $\begin{array}{c}\text { Average share of dwellings } \\
\text { destroyed in village }\end{array}$ \\
\hline 1 & Less than $20 \%$ & \\
\hline 2 & Between 20 and $70 \%$ & Less than $40 \%$ \\
\hline 3 & \multirow{3}{*}{ More than $70 \%$} & More than $40 \%$ \\
\hline 4 & &
\end{tabular}

Source: (European Commission 1999)

\subsection{Welfare}

The Kosovo LSMS has a number of variables that could be used to measure welfare, including income, assets and consumption. However, the income data is incomplete and does not allow us to calculate incomes from own businesses or from farming activities, and given the wide spread destruction of assets and the collapse of assets markets reported by Ogden (2000) and Westley and Mikhalev (2002), an accurate valuation of assets owned by households is not possible. Hence, in line with most of the welfare literature (see Deaton 1997) and in keeping with the spirit of the paper's aim to examine the ability of households to maintain consumption levels, we measure welfare using monthly household consumption per adult equivalent, using the equivalence scale suggested by the World Bank for Kosovo immediately after the conflict:

$$
E A=(A+0.75 * C)^{0.75}
$$

with $A$ the number of adult in the household and $C$ the number of children. The 'economies of scale' parameter of 0.75 (indicated by the power) is in line with conventional OECD equivalence scale, and suggests that economies of scale for larger households in Kosovo are limited (OECD 1982). The weight of 0.75 given to children (shown as the scalar for $C$ ) is very high compared to the conventional and newer OECD scales (Haagenars et al.1994) which assign a weight of 0.5 or 0.3 to children. This formula has been criticised by Beilock and Freeman (2006) for overestimating the consumption needs of the children of Kosovo and therefore for leading to an overestimation of the occurrence of poverty and extreme poverty among larger families. However, we have not attempted to adopt a different rescaling formula so as to remain consistent with previous research published on Kosovo (Bhaumik et al. 2006a, 2006b, 2008 and 2009). Also, as reported by Beilock and Freeman (2006), the World Bank indicated that they had no plans to adjust their formula in future rounds of data collection and analysis. So in the interests of comparability with other research on Kosovo, we have used this equivalence scale.

The definition of consumption is in line with standard LSMS procedures and includes food consumption, expenditure on a wide range of non-food items, rental values of consumer durables, and expenditures on education. ${ }^{2}$ In common with much of the livelihoods literature, we restrict our analysis to the rural population. This provides a more homogenous sample, in

2 In more detail, food consumption includes purchased food, stored food consumption, non-purchased food (home production and gifts or humanitarian aid using purchased food prices) and other daily expenditures on food (restaurant, fast-food, etc.). Expenditure on 'non-food items' includes personal items (clothing, personal care, entertainment and basic materials such as stationary) and housing services (laundry, cleaning, rent values of small items such as linens, dishes, small appliances and tools). Items and services received from aid and gifts were also included. Rental values of durables such as refrigerator, parabolic antenna, etc. The rental values were computed using self-reported values of each durable of different vintages using a quadratic depreciation pattern and a zero interest rate. Jewellery was excluded. See World Bank (2001c) for more details. 
the sense that identifying livelihood portfolios across both rural and urban households would be significantly more complex. Once cleaned from outliers and observations with missing values, the sample analysed includes 1418 rural households. A description of the discarded households is provided in Annex 1.

\section{Livelihoods and portfolio identification}

Central to our analysis is the definition of the livelihood portfolios of households. In the literature on livelihood diversification, these choices are usually captured in an ex post way, by the share of income derived from various sources (Barrett et al. 2001; Ellis 2000; Liyama et al. 2008; Reardon 1997; Wouterse and Taylor 2007). We are unable to adopt this approach because it is not possible with the Kosovo LSMS data to identify accurately the flow of incomes from different activities of the household. However, even if it were possible to do so, simply knowing the shares of income from for example agriculture, or off-farm employment, would tell us little about the range and combination of activities a household is engaged in. A more appealing approach is to seek to identify a set of mutually exclusive livelihood categories, or portfolios, where each category is a meaningful set of activities reflecting households' true choices. Good examples of such an approach include Carter and May (1999) and Eastwood et al. (2006) in their respective studies of South Africa.

Specifically and as an example, Carter and May draw on participatory techniques to classify households into one of eight livelihood classes, including marginalised households with no access to wages, remittances or transfers and with very low incomes; remittance dependent households; welfare dependent households; wage dependent households and entrepreneurial households. In the Kosovo context, and also using participatory approaches, Westley and Mikhalev (2002) identify a number of livelihood choices, such as reliance on remittances, working abroad, subsistence farming for household consumption, extended family/community safety nets, and humanitarian aid for the poorest and these are broadly in line with those identified by Ogden (2000).

Defining livelihood strategies and assigning households to these different strategies is always a difficult enterprise. Extensive local knowledge and data availability can allow for the objective construction of groupings based on observed characteristics (see for example Eastwood et al. (2006) as well as the Kosovo studies already discussed). However, often households appear to be grouped into strategies based on ad hoc criteria and arbitrary thresholds, especially when information is incomplete or when the identification of livelihood is to some degree exploratory. Brown et al. (2006) noted indeed, that despite its conceptual appeal and its importance to development practice, livelihood strategies remain difficult to operationalise and little consensus exists on best practices.

Quantitative methods, which do allow for objective and replicable categorisations of observations, are however available. Indeed, cluster analysis methods are meant exactly to be used in this type of context. They are based on a clustering algorithm, using objective distance criteria, and are used to construct groupings reflecting the underlying structure of the data. They are therefore both objective and data-oriented and allow for the creation of replicable and non-arbitrary classifications. They are frequently used in studies where it is important to capture heterogeneity among observations that are usually seen as a homogenous group. For example, Cunningham and Maloney (2001) use cluster analysis to highlight the different types of micro-enterprises existing in Mexico when most researchers tend to see self- employment in small businesses as a homogenous category. Similarly, a study by Liou and Ding (2002) provides evidence that 'small states' are often aggregated inappropriately in macroeconomic studies. A number of examples where clusters are used for the investigation of the impact of attitudes on decision making can also be found as it is often more meaningful to contrast the behaviour of groups with marked differences in 
attitudes and opinions rather than to focus on the mean attitude of individuals in the full sample of interest (e.g. Aerni and Bernauer 2006; Davies and Hodge 2006). Similarly, for the purposes of our study, clustering algorithms appear especially well suited to the construction of livelihood strategies and have been used on numerous occasions for this purpose (e.g. Brown et al. 2006; Jansen et al. 2006; Petrovici and Gorton 2005).

For example, Brown et al. (2006) use cluster analysis methods to operationalise the concept of livelihood strategies in household data for Kenya's central and western highlands. They identify five mutually exclusive livelihood strategies by examining how households allocate assets (land and family labour) across a range of different activities, including farm and offfarm, livestock and crop, food and non-food crops. The resulting clusters of part-time subsistence smallholders, mixed smallholders, staples producers, off-farm skilled employment and diversified commercial are found to have statistically significant differences in mean per capita incomes and welfare rankings. Only the latter group attain welfare levels above the dollar-a-day poverty line.

Jansen et al. (2006) focus on the hillside areas of Honduras and identify household categories based on the allocation of their main assets (again land and labour) across a range of activities. Their results highlight the higher welfare levels reached by households able to combine farming activities and non-farm waged labour.

Finally, Petrovici and Gorton (2005) use rurality, financial resources and time dedicated to the main household activity to cluster Romanian households into four groups. They identify four distinct groups, including two relying heavily on farming. Their results highlight that group-specific policy packages would be needed to alleviate poverty more effectively.

A concern with the use of clustering techniques is that some variables can be given disproportionately large weights in the analysis due to differences in scale or to collinearity among variables. A practical and non-arbitrary way of dealing with those issues is to use factor analysis prior to clustering. This allows practitioners to create a smaller set of synthetic factors expressed on similar scales and cleaned of any collinearity effects (see for instance Jansen et al. 2006 or Petrovici and Gorton 2005). However, Hair et al. (2005) reports that this practice can lead to strongly attenuating the discriminating power of some variables and can lead to the identification of groups that do not represent well the structure of the data. For this reason, synthetic factors should only be extracted and used for clustering when serious levels of correlation are observed in the data. In our data we conduct two standard tests, described in Hair et al. (2005), to establish that collinearity is not a significant issue. The first test is the Bartlett test of sphericity which tests the existence of interdependencies among variables. For our sample, the test indicates a significant level of interdependency. However, this was expected for a sample as large as ours and alone does not justify the use of factor analysis. The second test relies on the Kaiser-Meyer Olkin measure of sampling adequacy, a measure that takes values between 0 and 1 with higher values revealing an adequate fit of the data to factor analysis. For our sample, we find a value of just over 0.5 which indicates that our data has a 'miserable' fit to the factor analysis, i.e. factor analysis will not necessarily improve the clustering results. Hence we conclude that the clustering algorithm can be applied without prior factor analysis. The variables were, however, standardised prior to clustering so as to prevent scale effects.

The variables selected to define the clusters constitute the set of income sources, and is thus in line with the approach adopted by Carter and May (1999). These include (1) yearly wage income, (2) cultivable land, (3) value of livestock, (4) yearly remittances received, (5) yearly benefits or social assistance (that is to say pensions, maternity and sickness allowance, disability payments, etc.), (6) a measure of access to aid includes repair and food aid, UNMIK assistance and other aid) and (7) dummy equal to one if the household owns at least 
one non- farm business. All continuous variables were rescaled per adult equivalent, so as to factor out family scale effects, and normalised.

Table 3.1 clearly shows that most households live on a variety of income sources rather than a single activity. Agriculture appears to be widely spread in the rural population (with livestock and cultivable land being each found in more than 80 per cent and 90 per cent of the households respectively).

Table 3.1 Distribution of income sources in the rural sample

\begin{tabular}{|l|c|}
\hline \multicolumn{1}{|c|}{ Description } & Share (in \%) \\
\hline Households with more than one revenue source & 94.6 \\
\hline Households & \\
- with cultivable land & 90.1 \\
- with livestock & 81.7 \\
- receiving aid & 50.3 \\
- receiving at least one wage income & 50.2 \\
- receiving remittances & 39.4 \\
- receiving benefits & 10.5 \\
- with a non-farm business & 7.3 \\
\hline
\end{tabular}

The clustering algorithm produces a four cluster solution (see Annex 2 for details) that is described in Table 3.2, where we assess whether the variables used in the clustering discriminate between households. For the variables used in their logged form in the clustering process, the non-transformed variable is presented here to ease the description. All the variables entering the clustering procedure appear to have a significant discriminating effect, as the tests of overall differences among groups are all significant at the one per cent level (see the last column in Table 3.2).

Table 3.2 Cluster descriptions

\begin{tabular}{|c|c|c|c|c|c|}
\hline & Cluster 1 & Cluster 2 & Cluster 3 & Cluster 4 & $p_{\text {-value }}{ }^{a}$ \\
\hline Cluster size & 379 & 271 & 468 & 300 & \\
\hline \multicolumn{6}{|c|}{ Continuous variables (all pe): mean by cluster } \\
\hline $\begin{array}{l}\text { Cultivable } \\
\text { Land (ares) }\end{array}$ & $\begin{array}{c}17.06 \\
(19.11)\end{array}$ & $\begin{array}{c}32.98 \\
(40.25)\end{array}$ & $\begin{array}{c}23.55 \\
(27.35)\end{array}$ & $\begin{array}{c}23.70 \\
(28.90)\end{array}$ & 0.000 \\
\hline $\begin{array}{l}\text { Livestock } \\
\text { value (DM) }\end{array}$ & $\begin{array}{r}299.56 \\
(309.54)\end{array}$ & $\begin{array}{r}14.88 \\
(82.97)\end{array}$ & $\begin{array}{c}366.14 \\
(640.43)\end{array}$ & $\begin{array}{r}318.56 \\
(385.89)\end{array}$ & 0.000 \\
\hline Aid (DM) & $\begin{array}{r}296.92 \\
(787.86) \\
\end{array}$ & $\begin{array}{c}14.59 \\
(55.55) \\
\end{array}$ & $\begin{array}{r}300.02 \\
(859.16) \\
\end{array}$ & $\begin{array}{r}251.85 \\
(558.05) \\
\end{array}$ & 0.000 \\
\hline $\begin{array}{l}\text { Wage Income } \\
\text { (DM) }\end{array}$ & $\begin{array}{c}833.26 \\
(1786.20)\end{array}$ & $\begin{array}{c}145.34 \\
(564.27)\end{array}$ & $\begin{array}{c}310.77 \\
(900.03)\end{array}$ & $\begin{array}{c}128.19 \\
(703.46)\end{array}$ & 0.000 \\
\hline $\begin{array}{l}\text { Remittances } \\
\text { (DM) }\end{array}$ & $\begin{array}{r}2.15 \\
(9.33)\end{array}$ & $\begin{array}{c}48.78 \\
(333.27)\end{array}$ & $\begin{array}{c}979.73 \\
(1467.72)\end{array}$ & $\begin{array}{c}98.92 \\
(415.15)\end{array}$ & 0.000 \\
\hline $\begin{array}{l}\text { Benefits/Social } \\
\text { Assistance (DM) }\end{array}$ & $\begin{array}{r}1.22 \\
(9.17)\end{array}$ & $\begin{array}{c}134.91 \\
(454.99)\end{array}$ & $\begin{array}{c}1.46 \\
(10.49)\end{array}$ & $\begin{array}{r}0.30 \\
(3.22)\end{array}$ & 0.000 \\
\hline \multicolumn{6}{|c|}{ Dummy variable: share by cluster } \\
\hline $\begin{array}{l}\text { Non-farm own } \\
\text { business }\end{array}$ & $\begin{array}{r}0.00 \\
(0.00) \\
\end{array}$ & $\begin{array}{r}0.00 \\
(0.06) \\
\end{array}$ & $\begin{array}{r}0.00 \\
(0.05)\end{array}$ & $\begin{array}{c}0.34 \\
(0.47) \\
\end{array}$ & 0.000 \\
\hline
\end{tabular}

\footnotetext{
a Robust test of equality of mean (Brown-Forsythe)

b 1 are $=0.01$ hectare

Standard deviations are reported in parentheses.
} 
Observing the constitution of the different clusters we define them as follows:

Cluster 1 - households with wage incomes (WAGE) - appear to have by far the highest per adult equivalent wage income. They are poorly endowed with land, although retain some livestock. They receive few transfer in terms of remittances or social assistance, although have received significant amounts of aid.

Cluster 2 -dependents on social assistance (ASSIST) - are households that receive significantly higher levels of social assistance than any other cluster. However they receive very little aid. They are, on average, relatively well endowed with land but have little livestock.

Cluster 3 - highly diversified farmers with remittances (REM) - are highly diversified as a group with the over-riding feature that the mean level of remittances (per adult equivalent) is very high.

Cluster 4 - entrepreneurs (ENT) - are clearly characterised by their ownership of a non-farm business.

To profile further the clusters and investigate more of the characteristics of the groups formed, further tests of equality of means across groups can be performed, using variables that did not enter the clustering procedure. This allows for a fuller description of our clusters and constitutes an external validation of the groups formed (see Table 3.3).

Cluster 1, households with significant wage income (WAGE), includes households who have, on average, younger heads. They are likely to live in areas severely damaged during the war, and they are very likely to have been displaced during the conflict due to insecurity. They are predominantly ethnic Albanians, but unlike clusters 3 and 4 which are also predominantly ethnic Albanian, are less likely to have household members living abroad. Their average level of consumption is below the sample mean.

Cluster 2, households who are dependents on social assistances (ASSIST), is largely composed of Serb households, as well as smaller and older households. They tend to live in areas that have not been too severely damaged during the war and they are less likely to have been displaced. They tend to be located closer to municipal centres. However, they constitute the poorest group in the rural sample.

Cluster 3, the highly diversified farmers with remittances (REM), tend to live in areas that were severely damaged during the conflict and are likely to have been displaced for security reasons. Households in this cluster are more likely to have relatives who migrated away from Kosovo and this for the three different waves of migration considered here (when Kosovo was enjoying a relative autonomy - i.e. prior to 1990; during the slow escalation in ethnic tensions - i.e. between 1991 and 1997; and during and after the Kosovo war - i.e. between 1998 and 2000). Households in this cluster are among the better-off.

Finally cluster 4 , the entrepreneurial category, has been relatively more sheltered than the households in cluster 1 and 3. They live in areas that were slightly less severely damaged during the war and they are less likely to have been displaced for security reasons. Overall, these clusters have strong parallels to the qualitative descriptions of livelihoods adopted by rural households in Kosovo in the post conflict period as presented by Ogden (2000) and Westley and Mikhalev (2002). The clusters also share characteristics with those identified by other studies on livelihood portfolios. 
Table 3.3 Cluster profiling

\begin{tabular}{|c|c|c|c|c|c|}
\hline & WAGE & ASSIST & REM & ENT & $p_{\text {-value }}{ }^{a}$ \\
\hline Cluster size & 379 & 271 & 468 & 300 & \\
\hline \multicolumn{6}{|c|}{ Continuous variables: means by cluster } \\
\hline Age of head & 49.30 & 54.92 & 49.59 & 50.53 & 0.000 \\
\hline Household size & 7.70 & 4.77 & 6.93 & 7.78 & 0.000 \\
\hline $\begin{array}{l}\text { Share of adult members with up to primary } \\
\text { education }\end{array}$ & 0.51 & 0.44 & 0.52 & 0.51 & 0.006 \\
\hline $\begin{array}{l}\text { Share of adult members with up to } \\
\text { secondary education }\end{array}$ & 0.27 & 0.36 & 0.23 & 0.25 & 0.000 \\
\hline $\begin{array}{l}\text { Share of adult members with up to tertiary } \\
\text { education }\end{array}$ & 0.05 & 0.04 & 0.05 & 0.03 & 0.056 \\
\hline $\begin{array}{l}\text { Share of adult members with up to } \\
\text { vocational education }\end{array}$ & 0.04 & 0.04 & 0.05 & 0.05 & 0.443 \\
\hline Share of dependents in hh & 0.40 & 0.37 & 0.41 & 0.43 & 0.018 \\
\hline Expenditure per equiv.adult & 114.73 & 99.73 & 125.30 & 118.89 & 0.000 \\
\hline Total Farm size (ha) & 1.67 & 2.18 & 2.04 & 2.22 & 0.008 \\
\hline Distance to border $(\mathrm{km})$ & 19.86 & 16.83 & 18.51 & 17.71 & 0.000 \\
\hline Distance to municipal centre $(\mathrm{km})$ & 8.75 & 6.32 & 8.67 & 8.19 & 0.080 \\
\hline \multicolumn{6}{|c|}{ Dummy variables: proportions by cluster } \\
\hline Household still displaced & 0.15 & 0.07 & 0.09 & 0.10 & 0.002 \\
\hline Female head & 0.07 & 0.11 & 0.06 & 0.06 & 0.068 \\
\hline Ethnic Albanian head & 0.94 & 0.14 & 0.96 & 0.92 & 0.000 \\
\hline \multicolumn{6}{|c|}{ Households with international migrants, by year of departure } \\
\hline Prior to 1990 & 0.03 & 0.14 & 0.23 & 0.07 & 0.000 \\
\hline Between 1991 and 1997 & 0.12 & 0.09 & 0.39 & 0.15 & 0.000 \\
\hline Between 1998 and 2000 & 0.06 & 0.11 & 0.17 & 0.08 & 0.000 \\
\hline Household living in conflict area & 0.69 & 0.28 & 0.66 & 0.66 & 0.000 \\
\hline \multicolumn{6}{|c|}{ Damage to Local Infrastructure and Services, at community level, since 1997} \\
\hline Generator & 0.08 & 0.00 & 0.09 & 0.07 & 0.000 \\
\hline Electricity & 0.23 & 0.10 & 0.27 & 0.26 & 0.000 \\
\hline Piped water & 0.03 & 0.02 & 0.06 & 0.06 & 0.013 \\
\hline Television & 0.43 & 0.15 & 0.50 & 0.48 & 0.000 \\
\hline Satellite & 0.35 & 0.09 & 0.39 & 0.41 & 0.000 \\
\hline $\begin{array}{l}\text { Household displaced during conflict } \\
\text { for security reasons }\end{array}$ & 0.82 & 0.18 & 0.83 & 0.76 & 0.000 \\
\hline \multicolumn{6}{|l|}{ Household living: } \\
\hline in a temporary dwelling & 0.08 & 0.02 & 0.10 & 0.08 & 0.000 \\
\hline In a damaged dwelling & 0.51 & 0.55 & 0.43 & 0.46 & 0.008 \\
\hline Mine(s) on farm land & 0.01 & 0.03 & 0.02 & 0.03 & 0.451 \\
\hline
\end{tabular}

${ }^{a}$ Robust test of equality of mean (Brown-Forsythe)

Standard deviations are reported in parentheses. 


\section{The effect of war on livelihood choice and welfare outcomes}

Having identified mutually exclusive portfolios of activities, our analysis proceeds in two steps. We first analyse the determinants of livelihood portfolio selection, that is selection into one of the four mutually exclusive livelihood clusters identified above, before investigating the determinants of welfare in each group accounting for selection.

In the first step, we estimate a multinomial logit model, with the clusters constituting the limited dependent variable. This is itself an interesting exercise and sheds light on the role of different factors, including conflict, in nudging households into particular livelihood choices. A general formulation of the multinomial model is:

$$
P_{j}=\frac{\exp \left(\beta x_{j}\right)}{\sum_{j} \exp \left(\beta x_{j}\right)} \quad \text { for } \mathrm{j}=0,1, \ldots, \mathrm{J}
$$

Where $P_{j}$ is the probability of selecting portfolio $\mathrm{j}$, from a set of $\mathrm{J}+1$ portfolios (here $\mathrm{J}+1=4$ ) and $x_{j}$ is a vector of variables influencing the choice of portfolio. The parameters $\beta$ are to be estimated and are set to 0 for the reference portfolio, i.e. for $\mathrm{j}=0$.

In the second step, we investigate the determinants of welfare for each livelihood group. However, selection bias may exist if the selection into group is not independent from the welfare returns, i.e. if the households who select a given portfolio systematically do better, or worse with this set of activities than households picked up at random in the sample. To deal with selection bias, Heckman (1976) suggested a two-stage estimation method which was later adapted by Lee (1983) to situations, like ours, where observations are grouped in more than 2 categories. The underlying principle is that the multinomial logit model allows us to estimate a selection vector and to incorporate a selection term (also called 'Inverse Mills Ratio' and noted $\lambda$ ) into our welfare regressions. Following Lee (1983), we compute a portfolio specific $\lambda_{j}$ as follows:

$$
\lambda_{j}=\frac{\phi\left[J\left(\beta x_{j}\right)\right]}{\Phi\left[J\left(\beta x_{j}\right)\right]} \quad \text { for } \mathrm{j}=1,2,3,4
$$

Where $\phi(.$.$) and \Phi(.$.$) are the PDF and CDF of the standard normal distribution respectively,$ and $J(.$.$) is Lee's inverse of the standard normal CDF at P_{j}$.

A significant and positive (negative) sign on any of the lambdas in the group-specific welfare regressions indicates that the unobservables around livelihood choice are positively (negatively) and significantly correlated with welfare. That is, the fact a household selected into a certain livelihood is a significant determinant of higher (lower) levels of welfare than expected. This two-step method therefore enables us to test formally if there are any selection effects when evaluating welfare outcomes.

In order to test our hypothesis that the legacy of war might not be restricted to choice of livelihood but may pervade welfare outcomes as well, even after controlling for selection into a specific livelihood portfolio, we further test whether a number of conflict legacy variables have any statistically significant effect on households' portfolio selection and welfare.

We first present a simple analysis of welfare, for the whole sample, not controlling for selection into livelihood clusters, or allowing for different welfare outcomes between 
livelihood clusters. We then present summary results from the multinomial logit and a final set of welfare regressions, controlling for selection effects.

The results of a simple OLS 'welfare' specification using the full sample of 1418 rural households are displayed in Table 4.1. We have not here corrected for selection or disaggregated by livelihood cluster, however the results indicate that the household specific and demographic variables have the expected signs and significance. Bhaumik et al. (2006a and $2006 \mathrm{~b}$ ) present similar results (with per capita consumption, in logarithms as their dependent variable), in particular relating to the relatively poor outcomes for Serbs compared to ethnic Albanian households. What is surprising about our results is the absence of statistical significance of the variables that capture war. We see significance on only two of the war legacy variables: whether the household is living in a temporary dwelling and whether the household is living in a war-damaged dwelling. Both coefficients have the expected negative sign - that is, welfare is negatively affected by war - but we would have expected to see other war legacy variables displaying significant coefficients. A more disaggregated analysis, building on the post-war livelihood strategies adopted in rural Kosovo should thus provide more insights into the links between war legacies on portfolio choices and welfare outcomes.

Table 4.1 Consumption estimates for full sample, OLS

Full Sample In (consumption per equiv adult)

\begin{tabular}{|c|c|c|}
\hline VARIABLES & Coefficient & Standard Error \\
\hline Age of Head & $-0.00335^{\star \star \star}$ & $(0.00121)$ \\
\hline Female Head & -0.00826 & $(0.0517)$ \\
\hline Share of dependent members in hh & $-0.472^{\star \star *}$ & $(0.0600)$ \\
\hline Head has primary or secondary education ${ }^{a}$ & $0.0939 *$ & $(0.0495)$ \\
\hline Head has university education $^{a}$ & $0.269 * \star \star$ & $(0.0643)$ \\
\hline Farm land (ares) & $0.0308^{\star \star \star}$ & $(0.00593)$ \\
\hline Head is ethnic Albanian & $0.154^{\star \star}$ & $(0.0636)$ \\
\hline International Miarant prior to 1990 & $0.0801^{*}$ & $(0.0468)$ \\
\hline International Miarant between 1991 and 1997 & $0.151^{\star \star \star}$ & $(0.0292)$ \\
\hline International Miarant between 1998 and 2000 & $0.142^{\star * \star}$ & $(0.0479)$ \\
\hline Damaqe to Electricitv infrastructure & -0.0642 & $(0.0471)$ \\
\hline Damaqe to Piped Water infrastructure & 0.0337 & $(0.0965)$ \\
\hline Damaqe to Satellite infrastructure & 0.0195 & $(0.0438)$ \\
\hline $\mathrm{HH}$ displaced durina conflict for securitv reasons & 0.0108 & $(0.0458)$ \\
\hline Household in hiah damaqe area & 0.0552 & $(0.0421)$ \\
\hline Household livina in a temporarv dwellina & $-0.126^{\star \star}$ & $(0.0565)$ \\
\hline Household livina in a war-damaged dwellina & $-0.122^{\star \star *}$ & $(0.0329)$ \\
\hline Mine on household farm land & 0.0696 & $(0.0901)$ \\
\hline Constant & $4.674^{\star \star \star}$ & $(0.113)$ \\
\hline Observations & \multicolumn{2}{|c|}{1.418} \\
\hline R-squared & \multicolumn{2}{|c|}{0.151} \\
\hline
\end{tabular}

${ }^{\mathrm{a}}$ Reference group for education is Head has no formal education.

\subsection{Selection into livelihood clusters: the multinomial logit results}

For ease of exposition we present only summary results of the multinomial logit model. As predicted, the results in Table 4.2 (see over) indicate that the experience of war play out very differently across the livelihood clusters. We see that the worsening of infrastructure, such as 
electricity and water supply since the pre-war period, is negatively and significantly related to being in the wage labourer category. That is, households are less likely to take up 'wage labour' as part of their livelihood strategy if there has been a reduction in local infrastructure, namely electricity and water, since the war. The worsening of these same services does not predict whether households locate in the other livelihood clusters. We also observe that location in areas that have experienced widespread to damage (as identified by the Housing Damage Assessment Survey) are more likely to be in the wage labour cluster, while there is no significant link between damages and membership of other livelihood groups. These results possibly indicate that households in this cluster are highly dependent on the availability of wage jobs in the area, which in turns may be dependent on water and electricity being available, e.g. for factories and businesses to run, or higher demand for services in badly damaged areas.

Table 4.2 Summary results (sign and significance) of multinomial logit for war variables, land and ethnicity, by livelihood cluster

\begin{tabular}{|l|l|l|l|l|}
\hline Variable & $\begin{array}{l}\text { Wage } \\
\text { labourers }\end{array}$ & $\begin{array}{l}\text { Social } \\
\text { assistance }\end{array}$ & $\begin{array}{l}\text { Highly } \\
\text { diversified } \\
\text { with } \\
\text { Remittances }\end{array}$ & Entrepreneurs \\
\hline $\begin{array}{l}\text { Reduction in electricity since } \\
1997\end{array}$ & Negative * & Positive & Negative & Negative \\
\hline $\begin{array}{l}\text { Reduction in water supply } \\
\text { since 1997 }\end{array}$ & Negative $* * *$ & Positive & Positive & Positive \\
\hline $\begin{array}{l}\text { Lower satellite coverage } \\
\text { since 1997 }\end{array}$ & Negative & Negative & Positive & Positive \\
\hline $\begin{array}{l}\text { Household displaced during } \\
\text { conflict for security reasons }\end{array}$ & Positive & Negative & Positive & Negative \\
\hline Ethically Albanian & Positive $* * *$ & Negative & Positive & Positive \\
\hline $\begin{array}{l}\text { Damage intensity at the } \\
\text { village level }\end{array}$ & Positive $*$ & Negative & Negative & Positive \\
\hline Living in temporary dwelling & Positive & Positive & Negative & Negative \\
\hline Living in damaged dwelling & Positive & Positive & Negative & Negative \\
\hline Mine on land & Negative & Positive & Positive & Positive \\
\hline Distance to closest border & Positive & Positive & Negative & Negative \\
\hline Land area & Negative & Positive & \\
\hline
\end{tabular}

For social assistance and remittance-diversified households we see that household displacement due to insecurity and damaged dwelling significantly predicts whether households are likely to be in these livelihood clusters, but in different ways. Households are more likely to be reliant on social assistance if they live in a damaged dwelling than households that do not live in damaged dwellings, whereas the opposite holds for remittance- diversified households - if households live in a damaged dwelling they are less likely to be remittance-diversified. As for displaced households, there are some indications that Serbs, in our sample, were less likely to have been displaced during the war. The significant point estimate on the insecurity-displaced variable for membership in the cluster of households relying on social assistance may simply reflect this: Serbs are more frequent in this cluster and they were less likely to be displaced. The fact that displaced households are 
more likely to be in the remittance cluster could be an indication that displacement facilitated subsequent migration. It may also be that households who had migrants before the conflict may have found it easier to move away from their house and jobs during the war, if migrant remittances continued to be received.

Ethnicity strongly predicts livelihood cluster, with Albanian ethnicity being positive and strongly significant as a predictor of three clusters - wage-labourers, remittance- diversified and entrepreneurs - and a strong negative predictor of belonging to the social assistancedependent cluster. This result could reflect the political processes of inclusion/exclusion, based on ethnicity, which affected post-war Kosovo. Indeed, ethnic Serbs were reportedly receiving assistance from Belgrade which was not available to Albanians, while at the same time Serbs rejected the UN presence in Kosovo and it was reportedly difficult, at least initially, for some international organisations and NGOs to come and work in Serbian areas (see Ogden 2000, for example). Interestingly, this is in line with the reasoning of Bhaumik et al. (2006a and 2009) who argue that ethnic Serbs, despite being better endowed in physical and human capital, do not do as well as the ethnic Albanians. They point to political discrimination as a possible cause.

The distance-to-border variable performs as anticipated, negatively and significantly predicting selection in the entrepreneurial cluster. This makes sense and it is likely that much of the business and small-scale entrepreneurial activity is largely facilitated through crossborder trade after the war and therefore the greater the distance to the nearest border, the less likely the household will establish a livelihood based on small-scale entrepreneurialism.

These hypotheses require further investigation but are at least suggestive of two key points: (a) the experience of war varies across livelihood clusters, and (b) the effects of war on livelihood choice are not uniform. Furthermore, some of these differential links that we identified between war experience and livelihood point out towards the existence of both conflict-generated opportunities and constraints impacting on households choices.

\subsection{Selection effects on welfare}

In order to examine the effects of self-selection into a specific livelihood cluster on the welfare returns to the cluster we use a two stage selection model inspired from Heckman (1976) as discussed above. ${ }^{3}$ Table 4.3 presents the regression estimates. We include all war legacy variables in this specification. We see substantial variation in the significance of different coefficients across the livelihood cluster-specific welfare regressions. This variation was previously masked when we looked at full sample welfare regression as presented in Table 4.1.

The socio-demographic variables in our specifications have the expected signs and confirm the widely accepted positive effect of education on welfare in nearly all clusters, while an older household head and larger shares of dependents are associated with lower level of welfare. The role of subsistence farming and remittances as quasi-universal safety nets for households in Kosovo is confirmed by the fact that greater farm size means higher consumption for all clusters apart from the group relying on social assistance and the fact that the existence of migrating relatives is associated with higher level of welfare for all clusters. These results are consistent with those presented in Table 4.1 for the full sample. However, in line with the objective of the paper, we focus our discussion on two features: the evidence on the effect of war on welfare and the evidence on selection effects. 
Table 4.3 Welfare estimation results with correction for selectivity bias, by livelihood cluster

\begin{tabular}{|c|c|c|c|c|}
\hline VARIABLES & $\begin{array}{l}\text { Wage } \\
\text { labour }\end{array}$ & $\begin{array}{l}\text { Social } \\
\text { assistance }\end{array}$ & $\begin{array}{l}\text { Remittance } \\
\text { diversified }\end{array}$ & Entrepreneur \\
\hline Age of Head & $\begin{array}{l}-0.00595^{\star \star} \\
(0.00238)\end{array}$ & $\begin{array}{l}-0.00837^{* * *} \\
(0.00285)\end{array}$ & $\begin{array}{l}0.000245 \\
(0.00181)\end{array}$ & $\begin{array}{l}-0.00627^{* \star} \\
(0.00264)\end{array}$ \\
\hline Female Head & $\begin{array}{l}-0.0670 \\
(0.103)\end{array}$ & $\begin{array}{l}-0.0652 \\
(0.109)\end{array}$ & $\begin{array}{l}-0.0846 \\
(0.0971)\end{array}$ & $\begin{array}{l}0.0428 \\
(0.133)\end{array}$ \\
\hline Share of dependents & $\begin{array}{l}-0.408^{* \star *} \\
(0.116)\end{array}$ & $\begin{array}{l}-0.110 \\
(0.115)\end{array}$ & $\begin{array}{l}-0.638^{* * *} \\
(0.0851)\end{array}$ & $\begin{array}{l}-0.548^{* * *} \\
(0.150)\end{array}$ \\
\hline $\begin{array}{l}\text { Head has primary or secondary } \\
\text { education }\end{array}$ & $\begin{array}{l}0.0593 \\
(0.108)\end{array}$ & $\begin{array}{l}-0.0291 \\
(0.137)\end{array}$ & $\begin{array}{l}-0.00722 \\
(0.0664)\end{array}$ & $\begin{array}{l}0.109 \\
(0.119)\end{array}$ \\
\hline Head has university education & $\begin{array}{l}0.277^{\star} \\
(0.145)\end{array}$ & $\begin{array}{l}0.341^{* *} \\
(0.151)\end{array}$ & $\begin{array}{l}0.216^{\star \star} \\
(0.0952)\end{array}$ & $\begin{array}{l}-0.00733 \\
(0.206)\end{array}$ \\
\hline Total farm size (ha) & $\begin{array}{l}0.0530 * * \\
(0.0252)\end{array}$ & $\begin{array}{l}0.00198 \\
(0.0121)\end{array}$ & $\begin{array}{l}0.0325^{\star \star \star} \\
(0.00828)\end{array}$ & $\begin{array}{l}0.0252^{\star *} \\
(0.0121)\end{array}$ \\
\hline Head is ethnic Albanian & $\begin{array}{l}-0.0166 \\
(0.214)\end{array}$ & $\begin{array}{l}2.375^{\star * *} \\
(0.555)\end{array}$ & $\begin{array}{l}0.653^{* *} \\
(0.258)\end{array}$ & $\begin{array}{l}0.274 \\
(0.201)\end{array}$ \\
\hline $\begin{array}{l}\text { International Migrant: } \\
\text { pre } 1990\end{array}$ & $\begin{array}{l}0.00383 \\
(0.120)\end{array}$ & $\begin{array}{l}-0.0615 \\
(0.136)\end{array}$ & $\begin{array}{l}0.0820 \\
(0.0554)\end{array}$ & $\begin{array}{l}0.103 \\
(0.108)\end{array}$ \\
\hline $\begin{array}{l}\text { International Migrant: } \\
1991 \text { to1997 }\end{array}$ & $\begin{array}{l}0.0944 \\
(0.0809)\end{array}$ & $\begin{array}{l}0.262^{\star *} \\
(0.116)\end{array}$ & $\begin{array}{l}0.128^{\star \star \star} \\
(0.0436)\end{array}$ & $\begin{array}{l}0.171^{\star *} \\
(0.0772)\end{array}$ \\
\hline $\begin{array}{l}\text { International Migrant: } \\
1998 \text { to } 2000\end{array}$ & $\begin{array}{l}0.168^{\star \star} \\
(0.0758)\end{array}$ & $\begin{array}{l}0.104 \\
(0.132)\end{array}$ & $\begin{array}{l}0.0725 \\
(0.0546)\end{array}$ & $\begin{array}{l}0.344^{\star \star \star} \\
(0.100)\end{array}$ \\
\hline $\begin{array}{l}\text { Reduction in electricity: } \\
\text { Post } 1997\end{array}$ & $\begin{array}{l}-0.0305 \\
(0.0779)\end{array}$ & $\begin{array}{l}-0.558^{* *} \\
(0.232)\end{array}$ & $\begin{array}{l}-0.0541 \\
(0.0589)\end{array}$ & $\begin{array}{l}-0.00988 \\
(0.0952)\end{array}$ \\
\hline $\begin{array}{l}\text { Reduction in piped water: } \\
\text { Post } 1997\end{array}$ & $\begin{array}{l}0.190 \\
(0.210)\end{array}$ & $\begin{array}{l}-0.228 \\
(0.372)\end{array}$ & $\begin{array}{l}-0.0634 \\
(0.0986)\end{array}$ & $\begin{array}{l}0.151 \\
(0.161)\end{array}$ \\
\hline $\begin{array}{l}\text { Reduction in satellite: } \\
\text { Post } 1997\end{array}$ & $\begin{array}{l}0.0920 \\
(0.0791)\end{array}$ & $\begin{array}{l}0.132 \\
(0.198)\end{array}$ & $\begin{array}{l}0.0321 \\
(0.0568)\end{array}$ & $\begin{array}{l}0.0657 \\
(0.0835)\end{array}$ \\
\hline $\begin{array}{l}\text { Household displaced during } \\
\text { conflict for security reasons }\end{array}$ & $\begin{array}{l}-0.0557 \\
(0.0760)\end{array}$ & $\begin{array}{l}0.301^{\star *} \\
(0.119)\end{array}$ & $\begin{array}{l}0.0994 \\
(0.0722)\end{array}$ & $\begin{array}{l}0.00768 \\
(0.105)\end{array}$ \\
\hline $\begin{array}{l}\text { Household living in a highly } \\
\text { damaged area }\end{array}$ & $\begin{array}{l}0.0725 \\
(0.105)\end{array}$ & $\begin{array}{l}0.142^{\star} \\
(0.0813)\end{array}$ & $\begin{array}{l}-0.0550 \\
(0.0649)\end{array}$ & $\begin{array}{l}0.0600 \\
(0.0831)\end{array}$ \\
\hline $\begin{array}{l}\text { Household living in a temporary } \\
\text { dwelling }\end{array}$ & $\begin{array}{l}-0.180 \star \star \\
(0.0875)\end{array}$ & $\begin{array}{l}-0.580^{*} \\
(0.334)\end{array}$ & $\begin{array}{l}-0.0586 \\
(0.0874)\end{array}$ & $\begin{array}{l}-0.283^{\star \star} \\
(0.130)\end{array}$ \\
\hline $\begin{array}{l}\text { Household living in a damaged } \\
\text { dwelling }\end{array}$ & $\begin{array}{l}-0.100 \\
(0.0649)\end{array}$ & $\begin{array}{l}-0.179 * * \\
(0.0847)\end{array}$ & $\begin{array}{l}-0.211^{\star \star \star} \\
(0.0560)\end{array}$ & $\begin{array}{l}-0.351^{\star \star *} \\
(0.0716)\end{array}$ \\
\hline Mine on farm land & $\begin{array}{l}0.187 \\
(0.122)\end{array}$ & $\begin{array}{l}0.00314 \\
(0.171)\end{array}$ & $\begin{array}{l}0.174 \\
(0.181)\end{array}$ & $\begin{array}{l}-0.0516 \\
(0.147)\end{array}$ \\
\hline lambdaB1 & $\begin{array}{l}-0.127 \\
(0.302)\end{array}$ & & & \\
\hline lambdaB2 & & $\begin{array}{l}-1.314^{\star * *} \\
(0.282)\end{array}$ & & \\
\hline lambdaB3 & & & $\begin{array}{l}0.717^{* *} \\
(0.289)\end{array}$ & \\
\hline lambdaB4 & & & & $\begin{array}{l}0.454^{\star} \\
(0.251)\end{array}$ \\
\hline Constant & $\begin{array}{l}5.093^{\star \star \star} \\
(0.591)\end{array}$ & $\begin{array}{l}5.405^{\star \star \star} \\
(0.268)\end{array}$ & $\begin{array}{l}3.530 \star \star \star \\
(0.517)\end{array}$ & $\begin{array}{l}4.219 * \star \star \\
(0.517)\end{array}$ \\
\hline $\begin{array}{l}\text { Observations } \\
\text { R-squared }\end{array}$ & $\begin{array}{l}379 \\
0.132 \\
\end{array}$ & $\begin{array}{l}271 \\
0.216\end{array}$ & $\begin{array}{l}468 \\
0.215 \\
\end{array}$ & $\begin{array}{l}300 \\
0.246 \\
\end{array}$ \\
\hline
\end{tabular}


We first focus on selection effects. As hypothesised, we see that the welfare of households in different livelihood clusters is determined by the livelihood strategy they have selected in. Indeed, a number of Inverse Mills Ratios or lambdas turn out to have significant estimates in our group-specific regressions. More specifically, there are positive and significant (at the five per cent level and ten per cent level) selection effects for remittance- diversified households and entrepreneur households, respectively, but negative and significant (at the one per cent level) selection effect for social assistance households.

For the remittance-diversified group, the sign on the selection term suggests that households adopting this strategy experience higher welfare levels than a randomly selected household with average characteristics would be expected to experience. We observe the same effect for the entrepreneurial cluster. This suggests that households that select into these two clusters - highly diversified with remittances, or entrepreneurs - are better off partly because they have been able to select into these strategies. As discussed earlier, selection into the remittance diversified group was in part related to the existence of a history of migrant relatives and high level of internal displacement during the conflict which may have generated better post-war opportunities for households in this cluster, further strengthened by other unobservable characteristics. Similarly, selection into the entrepreneur cluster was in part related to the location of the household close to an international border, showing that quick access to neighbouring countries did allow for the development of profitable trade related activities.

The finding of positive selection effects for these two groups (remittance-diversified households and entrepreneur households) suggest that some households possess characteristic(s), unobservable in our data, that enables them to secure higher welfare. This may reflect their integration in a wide range of economic and social networks, and that these households were able to take advantage of new opportunities which may have paradoxically arisen from the fact that lives were disrupted and many households had to look at alternative routes (such as trading) to secure their welfare. Given the strong ethnic Albanian composition of this group, this may also reflect some of the discriminatory practices alluded to in Bhaumik et al. (2006a and 2009).

The negative and significant result on the selection term for those households largely dependent on social assistance indicates that households in this cluster achieve lower levels of welfare than a randomly selected household of mean characteristics. This suggests that these households, even though they appeared to be benefiting from well targeted social assistance, would have been better off had they been able to select any of the other three livelihood strategies. Because most of the households in this cluster are ethnic Serbs, this reinforces the idea expressed in Bhaumik et al. that the Serbian minority of post-war Kosovo was to some degree unable to take advantage of the opportunities opened to the Albanian majority.

Hence there is or are unobservable(s)/unexplainable characteristic(s) of households in this social assistance cluster that is/are negatively correlated with welfare. One may be inclined to think that this results is reflective of discrimination practices against Serbians during the post-war time, however this is an unlikely explanation. ${ }^{4}$ More plausible would be an explanation related to the constraints facing Serbs for access to wage labour, migration avenues and business opportunities within Kosovo immediately post-conflict.

Finally, we discuss the results relating to the question we posed at the start of the paper: does war affect welfare only via livelihood choices or does it affect welfare outcomes directly? Recall that we have controlled for selection into livelihood clusters, and that war 
variables were an important part of that selection. Any significant coefficients that emerge in the welfare regressions indicate that war has a further impact on welfare, beyond how it determines livelihood activities.

We do indeed observe several war variables with negative and statistically significant coefficients, indicating that war has a further detrimental effect on welfare that is not captured by livelihood choices. Living in a temporary or damaged dwelling lowers welfare for everyone. Perversely, having been displaced during the war for conflict reasons and living in an area with high damage are associated with higher welfare outcomes for those on social assistance, but has no effect on any of the other clusters. This may be because of the transfers from Belgrade that were targeted very much on Serbs in badly-affected areas.

\section{Discussion and conclusions}

Our initial analysis of the mean relationship between war legacies and welfare in post- war rural Kosovo revealed a very limited correlation between the two. However, qualitative studies conducted immediately after the war by Ogden (2000) and Westley and Mikhalev (2002) consistently highlighted the idea that conflict may have had a differential impact on households, depending on their livelihood strategy. Additionally, based on their quantitative analysis of welfare in post-war Kosovo, Bhaumik et al. also suggested that post-war political processes were reducing the livelihood opportunities of some section of the population in ways difficult to capture. Our main objectives here were therefore (i) to identify the livelihood strategies adopted by households in post-conflict rural Kosovo, (ii) to establish the determinants of livelihood selection and the specific role of war legacy variables in this selection and (iii) then to establish the determinants of welfare in each of the livelihood groups identified, controlling for war legacy variables and for the possibility of selection bias.

We were thus able to identify four distinctive livelihood strategies, reflecting differences in the opportunities and constraints faced by households post-conflict. In particular, our results highlighted the existence of a remittance-diversified livelihood strategy, associated with a long history of past migration, but also with higher level of mobility during the conflict. A more entrepreneurial livelihood strategy appeared to be open to households living closer to the borders of the region and mostly to ethnic Albanians. A strategy relying more on social assistance was identified and associated with lower level of displacements during the conflict and Serb ethnicity, probably reflecting the selectivity of some social assistance programs, but also the economic isolation of this group in the UN administered Kosovo province, and the difficulty they may have had to take part in alternative (and more lucrative) economic activities. Finally, our fourth livelihood strategy, the 'wage labourers' strategy, was mostly associated with higher level of damages and recent reduction in the level of infrastructure available, but also with Albanian ethnicity, smaller area of land farmed and higher likelihood of having resettled away from the household's pre-war dwelling. It may therefore be that this group reflect some form of 'reconstruction effort' effect, whereby wage labour opportunity were available to (mostly Albanian) households in the most conflict affected areas, even away from their own original living places, but only where the state of the infrastructures could permit the development of economic activities. This first exercise therefore revealed stronger and more nuanced effects of war on households' livelihood and highlighted the relevance of the concept of livelihood when discussing war experiences.

Building on this typology of livelihood strategies, we were then able to further characterise the impact of war and to identify differential impacts of war legacy variables on welfare. One specifically interesting result highlighted the fact that for households dependent on social assistance, those being worse affected by the conflict were enjoying higher level of welfare post-conflict (probably due to the targeting of the assistance they received). However, these 
households would have reached higher consumption level, had they been able to select into a different strategy (as revealed by the negative and significant lambda). On the other hand, two livelihood strategies showed positive and significant selection effects, indicating that the households in these strategies would have reached lower consumption level had they been selected in other groups. Specifically, both entrepreneurs and remittance diversified households were doing well thanks to them being able to select into these specific strategies.

This study has interesting policy implications. Indeed by approaching war experiences through the lens of the differing constraints and opportunities open to households, we are able to highlight the fact that more than social assistance, it is the widening of economic opportunities which helps improve the welfare situation of most. Our analysis clearly shows that those who are able to run small own-business or to engage in wage work or to rely on large networks of migrants do enjoy higher consumption levels, very soon after the end of the conflict, than those who can merely claim social assistance. Therefore, even though social assistance is probably a good short-term relief tool, it is only with better infrastructure (such as access to electricity, the development of a good road network or efficient money transfer facilities with the rest of the world) and the creation of economic opportunities than livelihoods can be rebuilt and strengthened.

Our work also emphasises the fact that the ethnic divide that persisted in post-war Kosovo meant that, in the immediate period after the war, the Serb minority could be seen as victims of the post-war situation: receiving substantial level of social assistance but unable to take part in more lucrative activities.

Looking at the political strategy that was implemented in Kosovo post war, we can highlight other interesting features of our results. Indeed, an early focus on agriculture in post-conflict Kosovo was heavily criticised for providing the wrong incentives: supporting a sector that might never be competitive (Lingard 2003) and preferring a short-run solution to a more complex approach that would be more fruitful. Beilock (2005) in particular insists that a focus on agriculture may appear to benefit a large majority (as everybody owns land and is engaged to some extent in agriculture) but would be counter-productive as the inactive land market would prevent people from selling land to invest in other activities, in effect locking rural household in subsistence farming. An approach focusing on a broader development of rural economic activities would be more beneficial. Similar recommendations can be found when transition countries are concerned, and where market imperfections restrict households' opportunities (Chaplin et al. 2004; Demirguc-Kunt and Klapper 2009). Our results support this finding. Indeed, even though we found that in nearly all the livelihood strategies that were adopted in post-war rural Kosovo access to more agricultural land (and therefore to more agricultural revenue) led to higher welfare levels, none of the strategies identified relied exclusively on farming. Furthermore, the more successful strategies were associated with access to non-farm income such as non-farm own-business and remittances. Policies need to focus on providing opportunities for diversifying rural activities.

Another feature of the Kosovo story is the role of remittances. As highlighted above, we also find that being part of a wide migrant network has important effects on welfare, raising incomes via receipt of remittances and spreading risk. More recently, a number of NGOs and local institution have called on remittances as a tool to promote growth in Kosovo (see Riinvest 2007 , for example), as remittances can help the family members that stay to invest in more productive activities, generating greater returns.

Finally, our results suggest that the impact of war goes beyond determining what households do, but affects the returns to those activities. This has important implications for reconstruction policies, which need to focus not just on developing and supporting livelihood activities and may need to encompass cash and in-kind transfers. 


\section{Annex 1 Discarded observations}

From an initial rural sample of 1440 households, 22 were discarded in this analysis. Nineteen of them were discarded due to missing values. In particular, a number of individuals indicated that they were employed and receiving a salary but failed to report their earnings and their households had to be dropped from the analysis. Three more observations were removed from the sample as outliers.

In a post-war situation, it may be more difficult to identify 'outliers' as one would expect a large degree of variation in the situations faced by households, especially in a country like Kosovo where the historical divide between Serbs and Albanians has meant that a number of opportunities and support measures were not available to both groups. In the sample of Kosovars investigated here, large variations can be observed in the returns household gets on per adult equivalent basis from the different activities considered. However, data transformation using logarithm smoothen the variables' distribution. The outliers' detection was therefore handled within the clustering process using the noise handling option in the TwoStep procedure at the default level of 25 per cent.

Clustering techniques are becoming increasingly popular (and sophisticated) as a tool to identify outliers (Duan et al. 2009), as they allow a fairly objective identification of anomalies and recognised that outliers may share common characteristics. Indeed, observations are clustered into a number of sub-groups with high within-group similarity and high between group differences, and outliers are identified as observations that cluster in separate small groups or observations that impact largely on the final clustering solution if removed. The noise handling option in the TwoStep procedure will classify as outliers observations that form small pre-clusters in the first step of the procedure and that affect the solution of the second step. The three observations discarded this way are households not receiving any form of aid, but receiving high level of remittances, they have very little land.

To assess the potential bias brought about by the discarding of observations, a Logit regression was performed. The dependent variable is equal to one if the observation was kept for analysis and 0 otherwise. The regression is performed using the full rural sample. The results are presented in Table A1 (see over) and indicate that the households kept for analysis tend to be smaller but with a greater share of dependents and are more likely to be living in highly damaged area (damage index equal to 3 or 4). Kept households do not differ from discarded one in terms of a number of variables including poverty levels (no significant differences in their average level of consumption), average number of displacement during the conflict and likelihood of living in a damaged dwelling.

The differences observed in the two sub-samples may mean that our results are slightly biased; however the bias is likely to be small as only 22 observations out of 1440 were discarded. Also, it is likely that the most vulnerable households and those more likely to have been affected by the conflict have not been discarded. 
Table A1 Characteristics of the observations kept, logistic regression

\begin{tabular}{|l|c|}
\hline & $\begin{array}{c}\text { Coefficient } \\
\text { (robust standard error) }\end{array}$ \\
\hline Expenditure per adult equivalent & 0.005 \\
Average number of displacement during conflict & $(-0.004)$ \\
Size of the household & -0.148 \\
Share of dependents & $(-0.118)$ \\
Dummy for ethnic Albanians & $-0.117^{\star}(-$ \\
Dummy for damage index level 2 & $0.067)$ \\
Dummy for damage index level 3 & $3.249^{\star \star *}$ \\
Dummy for damage index level 4 & $(-1.104)$ \\
Dummy for damaged dwelling & 0.374 \\
Constant & $(-0.638)$ \\
& 0.654 \\
& $(-0.577)$ \\
\hline Pseudo R-squared & $2.128^{\star \star *}(-$ \\
Sample size (rural population only) & $0.806)$ \\
\hline
\end{tabular}

*** significant at $1 \%,{ }^{* *}$ significant at $5 \%,{ }^{*}$ significant at $10 \%$ Regression

performed with sampling weights. 


\section{Annex 2 Cluster analysis methods and robustness check}

A number of clustering techniques are available to practitioners. They are most commonly classified in three categories: hierarchical, non-hierarchical or k-mean, and two-step techniques. The choice of the methods depends on the characteristics of the sample and the objectives of the practitioner. Hierarchical techniques are intuitively simple as they aggregate observations in successive stages and allow practitioners to determine the optimal number of clusters using a specified distance measure. However, these techniques are very sensitive to outliers and early wrong association will have great impacts. Also they are computationally demanding and therefore not adapted to large samples. K-mean clustering techniques are less sensitive to outliers and less computationally demanding. However the clustering process starts around a number of pre-defined seed-observations that need to be selected in a non-random fashion and that pre-determine the final number of clusters formed. The third type of method, combining hierarchical and non-hierarchical techniques, has recently been used more extensively as it appears to mitigate their drawbacks (Hair et al. 2005). First, a hierarchical technique is used to identify appropriate cluster seeds, and then observations are clustered using a non-hierarchical method around these initial seed points. This combined procedure is appropriate for large sample and very easy to implement through the SPSS TwoStep procedure and it is the procedure adopted here.

The distance between clusters is computed using a log-likehood distance measure, which allows for distance to be computed among observations when not all variables are continuous, as it is the case here. To decide how many clusters exist in the data, we need to minimise the distance between observations in a cluster, while maximising the distance between clusters. Here the optimal grouping is determined using standard criteria (Bacher et al. 2004) based on the change in BIC observed with the inclusion of an additional group, which is used as a measure of the relative improvement obtained in the fit of the solution, and the ratio of distance measure, which captures the overall dissimilarity of the groups formed. The optimal grouping will be identified as the cluster solution with the largest possible distance ratio, among those with a change in BIC of at least 0.04 . The solution selected in our analysis using those criteria, the clusters formed and their characteristics are discussed further in the result section.

A number of robustness checks were performed to insure the clusters were stable. Among these, potential inconsistencies in reporting activities were cross-checked using household members' employment status. Table A2 (see over) shows that household members' reported activities are consistent with cluster membership as described in the article. 
Table A2 Cluster and household labour allocation

\begin{tabular}{|c|c|c|c|c|c|}
\hline & Cluster 1 & Cluster 2 & Cluster 3 & Cluster 4 & Significance $^{\mathrm{a}}$ \\
\hline Group size & 379 & 271 & 468 & 300 & \\
\hline \multicolumn{6}{|c|}{ Continuous variables: mean for cluster } \\
\hline \multicolumn{6}{|c|}{ Among the working-age household members } \\
\hline $\begin{array}{l}\text { Share of members } \\
\text { actually working }\end{array}$ & $\begin{array}{c}0.49 \\
(0.27) \\
\end{array}$ & $\begin{array}{c}0.39 \\
(0.25) \\
\end{array}$ & $\begin{array}{c}0.55 \\
(0.34) \\
\end{array}$ & $\begin{array}{c}0.50 \\
(0.22) \\
\end{array}$ & $\star \star \star *$ \\
\hline \multicolumn{6}{|c|}{ Among the working household members } \\
\hline $\begin{array}{l}\text { Share holding several } \\
\text { jobs }\end{array}$ & $\begin{array}{c}0.13 \\
(0.28)\end{array}$ & $\begin{array}{c}0.09 \\
(0.24)\end{array}$ & $\begin{array}{c}0.08 \\
(0.21)\end{array}$ & $\begin{array}{c}0.16 \\
(0.27)\end{array}$ & ** \\
\hline $\begin{array}{l}\text { Share self- employed off- } \\
\text { farm }\end{array}$ & $\begin{array}{c}0.14 \\
(0.30)\end{array}$ & $\begin{array}{c}0.14 \\
(0.32)\end{array}$ & $\begin{array}{c}0.00 \\
(0.00)\end{array}$ & $\begin{array}{c}0.44 \\
(0.37)\end{array}$ & *** \\
\hline Share with paid job & $\begin{array}{c}0.32 \\
(0.33)\end{array}$ & $\begin{array}{c}0.24 \\
(0.32)\end{array}$ & $\begin{array}{c}0.14 \\
(0.26)\end{array}$ & $\begin{array}{c}0.12 \\
(0.19)\end{array}$ & *** \\
\hline $\begin{array}{l}\text { Share self- employed on- } \\
\text { farm }\end{array}$ & $\begin{array}{c}0.50 \\
(0.41)\end{array}$ & $\begin{array}{c}0.51 \\
(0.43)\end{array}$ & $\begin{array}{l}0.70 \\
(0.39)\end{array}$ & $\begin{array}{c}0.42 \\
(0.36)\end{array}$ & *** \\
\hline \multicolumn{6}{|c|}{ Dummy variable: share by cluster } \\
\hline $\begin{array}{l}\text { Household with under- } \\
\text { age or over- age workers }\end{array}$ & $\begin{array}{r}0.16 \\
(0.37)\end{array}$ & $\begin{array}{r}0.14 \\
(0.35)\end{array}$ & $\begin{array}{r}0.25 \\
(0.44)\end{array}$ & $\begin{array}{r}0.19 \\
(0.39)\end{array}$ & ** \\
\hline
\end{tabular}

\footnotetext{
a Robust test of equality of mean (Brown-Forsythe)

${ }^{* * *}$ significant at $1 \%,{ }^{* *}$ significant at $5 \%,{ }^{*}$ significant at $10 \%$ Standard deviations are reported in parentheses.
} 


\section{References}

Aerni, P. and Bernauer, T. (2006) 'Stakeholder Attitudes toward GMOs in the Philippines, Mexico, and South Africa: The Issue of Public Trust', World Development 34.3: 557-75

Alva, S.; Murrugarra, E. and Paci, P. (2002) The Hidden Costs of Ethnic Conflict Decomposing Trends in Educational Outcomes of Young Kosovars, Policy Research Working Paper 2880, Washington DC: World Bank

Bacher, J.; Wenzig, K. and Vogler, M. (2004) SPSS TwoStep Cluster - A First Evaluation, Arbeits- und Diskussionspapiere - Friedrich-Alexander Universität, 2004.2

Barrett, C.B.; Reardon, T. and Webb, P. (2001) 'Non-farm Income Diversification and Household Livelihood Strategies in rural Africa: Concepts, Dynamics, and Policy Implications', Food Policy 26.4: 315-31

Beilock, R. (2005) 'Rethinking Agriculture and Rural Development in Kosovo', South-Eastern Europe Journal of Economics 3.2: 221-48

Beilock, R. and Freeman, J. (2006) 'Crying Wolf: Rectifying Poverty Rates in Kosova', Journal of Income Distribution 15 (Index issue): 147-66

Bhaumik, S.K.; Gang I.N. and Yun, M-S. (2006a) 'Ethnic Conflict and Economic Disparity: Serbians and Albanians in Kosovo', Journal of Comparative Economics 34.4: 754-73

_ (2006b) 'A Note on Poverty in Kosovo', Journal of International Development 18: 1177-87

- (2008) Gender and Ethnicity in Post-Conflict Kosovo, United Nations University World Institute for Development Economics Research, UNU-WIDER Research Paper 2008/43, Helsinki

_ (2009) 'Rationality as a Barrier to Peace: Micro-evidence from Kosovo', Comparative Economic Studies 51.2: 242-64

Binswanger, H. (1981) Attitudes Toward Risk: Theoretical Implications of an Experiment in Rural India, Artefactual Field Experiments 0009, The Field Experiments Website

Block, S. and Webb, P. (2001) 'The Dynamics of Livelihood Diversification in Post-Famine Ethiopia', Food Policy 26.4: 333-50

Bozzoli, C. and Bruck, T. (2009) 'Agriculture, Poverty, and Post-war Reconstruction: MicroLevel Evidence from Northern Mozambique', Journal of Peace Research 46.3: 377-97

Brown, D.R.; Stephens, E.C.; Okuro Ouma, J.; Murithi, F.M. and Barrett, C.B. (2006) 'Livelihood Strategies in the Rural Kenyan Highlands', African Journal of Agricultural and Resource Economics 1.1: 21-36

Bundervoet, T. (2010) 'Assets, Activity Choices, and Civil War: Evidence from Burundi', World Development 38.7: 955-65 
Calero, C.; Bedi, A.S. and Sparrow, R. (2009) 'Remittances, Liquidity Constraints and Human Capital Investments in Ecuador', World Development 37.4: 1143-54

Carter, F.W. (1993) 'Ethnicity as a Cause of Migration in Eastern Europe', GeoJournal 30.3: 241-48

Carter, M.R. and May, J. (1999) 'Poverty, Livelihood and Class in Rural South Africa', World Development 27.1: 1-20

Chaplin, H.; Davidova, S. and Gorton, M. (2004) 'Agricultural Adjustment and the Diversification of Farm Households and Corporate Farms in Central Europe', Journal of Rural Studies 20.1: 61-77

Cunningham, W.V. and Maloney W.F. (2001) 'Heterogeneity among Mexico's Microenterprises: An Application of Factor and Cluster Analysis', Economic Development and Cultural Change 50.1: 131

Davies, B.B. and Hodge I.D. (2006) 'Farmers' Preferences for New Environmental Policy Instruments: Determining the Acceptability of Cross Compliance for Biodiversity Benefits', Journal of Agricultural Economics 57.3: 393-414

Deaton, A. (1997) The Analysis of Household Surveys: A Microeconometric Approach to Development Policy, Baltimore MD and London: Johns Hopkins University Press

Deininger, K. and Okidi, J. (2003) 'Growth and Poverty Reduction in Uganda, 1999-2000: Panel Data Evidence', Development Policy Review 21.4: 481-509

Demirguc-Kunt, A. and Klapper L.F. (2009) Entrepreneurship in Post-Conflict Transition: The Role of Informality and Access to Finance, World Bank Policy Research Working Paper 4935

Dercon, S. (2005) 'Risk, Poverty and Vulnerability in Africa', Journal of African Economies 14: $483-88$

_ (1998) 'Wealth, Risk and Activity Choice: Cattle in Western Tanzania', Journal of Development Economics 55: 1-42

Dercon, S. and Krishnan, P. (1996) 'Income Portfolios in Rural Ethiopia and Tanzania: Choices and Constraints', Journal of Development Studies 32.6: 850-75

Duan, L.; Xu, L.; Liu, Y. and Lee, J. (2009) 'Cluster-based Outlier Detection', Annals of Operations Research 168: 151-68

Eastwood, R.; Kirsten, J. and Lipton, M. (2006) 'Premature Deagriculturalisation? Land Inequality and Rural Dependency in Limpopo Province, South Africa', Journal of Development Studies 42.8: 1325-49

Ellis, F. (2000) 'The Determinants of Rural Livelihood Diversification in Developing Countries', Journal of Agricultural Economics 51.2: 289-302

European Commission (1999) Emergency Assessment of Damaged Housing and Local/Village Infrastructure in Kosovo, http://reliefweb.int/node/407024 (accessed 16 October 2009) 
Fafchamps, M.; Udry, C. and Czukas, K. (1998) 'Drought and Saving in West Africa: Are Livestock a Buffer Stock?', Journal of Development Economics 55: 273-305

Hagenaars, A.; de Vos, K. and Zaidi, M.A. (1994) Poverty Statistics in the Late 1980s: Research Based on Micro-data, Luxembourg: Office for Official Publications of the European Communities

Hair, J.F.; Black, W.C.; Babin, B.J.; Anderson, R.E. and Tatham, R.L. (2005) Multivariate Data Analysis, Sixth edition, Pearson-Prentice Hall

Heckman, J. (1976) 'The Common Structure of Statistical Models of Truncation, Sample Selection, and Limited Dependent Variables and a Simple Estimator for such Models', Annals of Economic and Social Measurement 5: 475-92

Ibanez, A.M. and Velez, C.E. (2008) 'Civil Conflict and Forced Migration: the Micro Determinant and Welfare Loss of Displacement in Colombia', World Development 36: 69-676

Jansen, H.G.P.; Pender, J.; Damon, A.; Wielemaker, W. and Schipper, R. (2006) 'Policies for Sustainable Development in the Hillside Areas of Honduras: a Quantitative Livelihoods Approach', Agricultural Economics 34.2: 141-53

Justino, P. and Verwimp, P. (2008) Poverty Dynamics, Violent Conflict and Convergence in Rwanda, MICROCON Research Working Paper 4, Brighton: IDS

Lee, L.F. (1983) 'Generalized Econometric Models with Selectivity', Econometrica 51: 507-12

Lingard, J. (2003) 'A Comparative Advantage Analysis of Kosovan Agriculture', PostCommunist Economies 15.3: 417-34

Liou, F.M. and Ding, C.G. (2002) 'Subgrouping Small States Based on Socioeconomic Characteristics', World Development 30.7: 1289-306

Liyama, M.; Kariuki, P.; Kristjanson, P.; Kaitibie, S. and Maitima, M. (2008) 'Livelihood Diversification Strategies, Incomes and Soil Management Strategies: A Case Study from Kerio Valley, Kenya', Journal of International Development 20.3: 380-97

Morduch, J. (1995) 'Income Smoothing and Consumption Smoothing', Journal of Economic Perspectives 9.3: 103-14

OECD (1982) The OECD List of Social Indicators, Paris: OECD

Ogden, K. (2000) 'Coping Strategies Developed as a Result of Social Structure and Conflict: Kosovo in the 1990s', Disasters 24.2: 117-32

Petrovici, D.A. and Gorton, M. (2005) 'An Evaluation of the Importance of Subsistence Food Production for Assessments of Poverty and Policy Targeting: Evidence from Romania', Food Policy 30.2: 205-23

Reardon, T. (1997) 'Using Evidence of Household Income Diversification to Inform Study of the Rural Nonfarm Labor Market in Africa', World Development 25.5: 735-48 
Riinvest (2007) Diaspora and Migration Policy, study prepared for Forum 2015 by the Riinvest Institute, www.riinvestinstitute.org/index.php?gjuha=en\&action= meshume\&cid=2\&sid=14\&id=81 (accessed 21 October 2011)

Rosenzweig, M.R. and Wolpin, K.I. (1993) 'Credit Market Constraints, Consumption Smoothing, and the Accumulation of Durable Production Assets in Low-income Countries: Investment in Bullocks in India', Journal of Political Economy 101.2: 223-44

Sklias, P. and Roukanas, S. (2007) 'Development in Post-Conflict Kosovo', South-Eastern Europe Journal of Economics 2: 267-87

Smit, A.R. (2006) 'Housing and Property Restitution and IDP Return in Kosovo', International Migration 44.3: 63-88

Westley, K. and Mikhalev, V. (2002) The Use of Participatory Methods for Livelihood Assessment in Situations of Political Instability: A Case Study from Kosovo, ODI Working Paper 190

World Bank (2001a) Kosovo Poverty Assessment, Volume I, World Bank Report 23390-KOS, Poverty Reduction and Economic Management Unit, Europe and Central Asia Region

_ (2001b) Kosovo Poverty Assessment, Volume II, World Bank Report 23390-KOS, Poverty Reduction and Economic Management Unit, Europe and Central Asia Region

- (2001c) Kosovo Living Standards Measurement Study Survey 2000, Basic Information Document, Poverty and Human Resources Development Research Group, the World Bank

Wouterse, F. and Taylor, J.E. (2007) 'Migration and Income Diversification: Evidence from Burkina Faso', World Development 36.4: 625-40 